\title{
Escrever, ferir, traduzir: o corpo-a-corpo da escrita entre Memórias do cárcere $e$ Memóires de prison
}

\author{
Aryadne Bezerra de Araújo (UESC)* \\ https://orcid.org/0000-0003-0645-9560 \\ Élida Paulina Ferreira (UESC)** \\ https://orcid.org/0000-0001-5513-9366
}

\section{Resumo:}

Argumentamos que Memórias do cárcere, de Graciliano Ramos, e sua tradução em Mémoires de prison encenam a noção que Jacques Derrida (1986, 1992, 2007) enseja de escrita como a abertura de um ferimento que lamenta e testemunha o instante não mais presente da sua efração. 0 processo narrativo das Memórias põe em movimento um constante embate para exumar o passado traumático, reabrindo a ferida para o testemunho do leitor. Partindo do contato com as "agruras" do outro, a tradução para o francês se desdobra de modo que as impressões do contato com o relato pungente de Graciliano influenciam nas transformações que os tradutores operam no corpo do texto. Nesse cenário, tem lugar um "corpo-a-corpo" na língua e na escrita, ao qual Derrida (2007) alude. Por meio desse movimento, o original, que já não é pleno e imune a fissuras, é ferido, porém, ao mesmo tempo, sobrevive e continua a testemunhar na escrita tradutória. Discutimos como a escrita do trauma gera em si uma fissura na trama testemunhal de Graciliano Ramos e como Mémoires de prison a revela, ao passo que abre ainda mais a cesura. Nossa análise parte da leitura do primeiro volume da obra - Viagens - e da tradução. Palavras-chave: Tradução; Jacques Derrida; Memórias do cárcere; Escrita testemunhal.

\section{Abstract:}

\section{Writing, wounding, translating: the corps à corps of writing between Memoirs of prison and Memóires de prison}

We argue that Memoirs of prison, by Graciliano Ramos, and its translation in Mémoires de prison, enact the notion of writing as the opening of a wound

* Doutoranda em Letras: Linguagens e Representações (UESC). Bolsista da Fundação de Amparo à Pesquisa do Estado da Bahia - FAPESB. E-mail: aryadne.araujo@gmail.com

** Professora Titular da Universidade Estadual de Santa Cruz. Docente do Programa de Pós-Graduação em Letras - Linguagens e Representações. E-mail: epferreira@uesc.br 
that Jacques Derrida's thought gives rise. That wound in writing mourns and testifies to the moment of its emergence that is no longer present. The narrative process in Memoirs of prison sets in motion a constant struggle to exhume the traumatic past, reopening the wound for the reader's testimony. The French translation unfolds from the contact with the "hardships" of Graciliano's pungent narrative, in such a way that impressions from this contact influence the transformations translators operate in the text body. In this scenario, a "corps à corps", to which Derrida (2007) alludes, takes place in language and writing. Through this movement, the original, which is not complete and immune to fissures, is wounded, but at the same time, it survives and keeps testifying in the translation. We reflect on how trauma writing generates a wound in Graciliano's testimony and how Mémoires de prison reveals that wound, while turning its opening even wider. Our analysis is based on the first volume of the book - Voyages - and its translation.

Keywords: Translation; Jacques Derrida; Memoirs of Prison; Testimonial writing.

\section{Introdução}

No preâmbulo das suas Memórias do cárcere, Graciliano Ramos se vale das metáforas da "exumação" e da descida à cova para traduzir o relato e o processo escritural - que mergulha no subterrâneo do passado traumático e desenterra suas reminiscências. Vemo-nos, então, diante de uma escrita que manifesta a (re)abertura e, ao mesmo tempo, o esforço de cicatrização de uma ferida. A linguagem do testemunho do cárcere traz a lume a marca da violência inscrita no corpo, assim como podemos ler nos exemplos expressivos dos "dolorosos sulcos negros" (RAMOS, 1954, p. 66), dos quais o narrador se queixa, tanto no vazio do estômago pela inapetência como nas lacunas da memória, ambos deflagrando vertigens e confusões mentais.

0 trauma é, portanto, traduzido na escrita de um "eu" "esmagado", "pulverizado" e "despersonalizado" na prisão arbitrária à qual foi submetido. A lei desconhecida ${ }^{1}$ que

1 Graciliano Ramos clama nas suas Memórias que sua condenação ocorreu sem que ele soubesse as razões que a motivaram. Ele permaneceu pre- o aprisiona imprime no sujeito as marcas da injustiça. Tal impressão não ocorre fora de um corpo, lembra-nos Ana Kiffer (2006, p. 265), "uma vez que corresponde a um 'encontro ou contato de um corpo sobre outro', ou 'marca ou sinal deixado pela pressão de um corpo sobre outro'”. Nesse sentido, a impressão dessas marcas estende-se também ao ato de fincar e deixar rastros que, por sua vez, ensejam significados. Em outros termos, o corpo marcado fala e transmite sentidos nas chagas e nas cicatrizes impressas sobre ele, que, como tais, rememoram o acontecimento da sua irrupção. Gestando significações e leituras nesses traços fincados na pele, o corpo já se oferece como escrita da violência da lei e do Estado.

Quando a escrita singular do corpo invade as páginas de um relato testemunhal, Graciliano expõe, a partir de uma lógica opressora, um elo entre a lei coercitiva e a língua, elo também elucidado por Kiffer (2006). A trama que ata essas duas forças

so durante dez meses sem ser submetido a um processo jurídico. 
se faz notável no momento em que o autor sentencia: "liberdade completa ninguém desfruta: começamos oprimidos pela sintaxe e acabamos às voltas com a Delegacia de Ordem Política e Social, mas, nos estreitos limites a que nos coagem a gramática e a lei, ainda nos podemos mexer" (RAMOS, 1954, p. 6). Se a lei cortante, pela violência que imprime no corpo, vincula-se à língua, é porque, para Graciliano Ramos, a língua supõe também certa violência. Nessa perspectiva, Kiffer (2006, p. 267) assevera: "tanto o castigo quanto a linguagem associam memória e marcas ao corpo. Este deixa de ser puramente físico ao se fazer memória". Fazendo-se memória, o corpo se faz também escrita, o que reforça o argumento anterior. A escrita da testemunha abre sua passagem, fissurando o terreno da linguagem e sendo por ele ferido, num corpo-a-corpo na língua, numa escrita cuja passagem não se dá sem a violência no corpo (DERRIDA, 2007).

A narrativa do cárcere encena a "violência" da qual Derrida (2007) fala ao rasurar a trama da língua constituída por significações pretensamente estáveis e iteráveis que assegurariam uma transmissão "transparente" e "plena" do acontecimento. São traços dessa fissura as metáforas que aludem à chaga, ao espaço hospitalar e funerário, ou seja, às palavras que o autor manuseia e desloca de um determinado espaço a outro - do hospital ao cárcere, da cova à memória silenciada até sua exumação da escrita.

Como também lemos na escrita tradutória, algumas dessas expressões ora recriam o corpo esmagado, pulverizado - "nous avons l'impression qu'on désire seulement nous écraser, nous pulvériser2 [...]" (RAMOS, 1988, p. 54) - , com o ventre aberto sobre o leito de um hospital - "peut-être me trouvais-je à nouveau dans l'hôpital,

2 Todos os grifos nesse parágrafo são nossos. le ventre déchiré, brûlant de fièvre?" (RAMOS, 1988, p. 124) -, ora representam o movimento da queda e do mergulho - "un écroulement s'était produit. Indispensable d'en retirer des bribes de vie [...]. Faute de quoi, ce serait le désastre total, le plongeon définitif" (RAMOS, 1988, p. 50) -, ou aproximam da escrita penosa o ato de exumar - Je n'aimerais pas offenser quelqu'un avec cette exhumation. [...] J'ai déjè un pied dans la tombe [...]" (RAMOS, 1988, p. 24) ${ }^{3}$.

Como se faltassem palavras "dentro" daquele contexto que dessem conta de representar sua experiência, o autor e os tradutores se servem de significantes que apontam para outras circunstâncias - precisamente de dor e angústia - em torno de um corpo supliciado.

Contornando esse ângulo das Memórias, é possível antecipar que, para além de uma relação conflituosa entre trauma e linguagem, uma blessure4 surge na escrita no instante mesmo em que esta abre sua passagem na língua (DERRIDA, 1992, 2003, 2007). Portanto, não se trata somente de uma ofensa inominável que o autor travaria uma luta com "sua” língua para traduzir. Há

3 Trechos em Memórias do cárcere (grifos nossos): 1. "Temos a impressão de que apenas desejam esmagar-nos, pulverizar-nos [...]" (RAMOS, 1954, p. 45); 2. "Talvez me achasse de novo no hospital, com o ventre rasgado, a queimar de febre" (RAMOS, 1954, p. 137); 3. "Sucedia um desmoronamento. Indispensável retirar dele migalhas de vida [...]. De outro modo, seria o desastre completo, o mergulho definitivo" (RAMOS, 1954, vol. 1, p. 41); 4. "Ser-me-ia desagradável ofender alguém com esta exumação. (...) Estou a descer para a cova [...]" (RAMOS, 1954, p. 8).

4 Palavra que, em francês, alude tanto a uma lesão infligida no corpo como a uma ofensa, a um dano moral profundo, a um trauma. Derrida (1992, 2007) se vale desse significante para aludir também uma incisão no corpo textual em decorrência de um elo estremecido com "sua" língua, com os acontecimentos referenciados, com os tradutores e com a língua do outro no processo tradutório. 
também a tensão nessa luta que a escrita põe em movimento, ou seja, há trauma na escrita em si, na passagem do acontecimento à língua, passagem que não se dá sem que uma ferida irrompa na cena escritural.

É a partir desse cenário estremecido que a tradução se desdobra em Mémoires de prison. Os tradutores elevam uma blessure testemunhada no original quando atestam, em prefácio, o estilo "acerado" de Graciliano Ramos, isso que compõe sua linguagem singular e pungente, e quando, por outro lado, no texto em francês, transformam e deslocam esse traço, dando a entrever uma outra cisão na escrita tradutória. A tradução, portanto, se desenrola entre duas violências, a chaga do outro que atravessa a cena da escrita, afetando quem diante dela se põe, e a sujeição do corpo textual de Graciliano às normas de outra língua - violência sempre implicada no ato de traduzir (DERRIDA, 2007).

Examinaremos, na leitura de Mémoires de Prison, como esses dois abalos confluem no testemunho de uma différance 5 irredutível que revela a escrita tradutória como uma outra ferida. Para tanto, realçaremos trechos emblemáticos da tradução que, transformando o corpo textual das Memórias, ora colocam em relevo uma ferida contundente no texto original, ora atenuam a secura da sua linguagem lacônica, ou buscam, em certos momentos, preencher uma abertura dei-

5 Transformação que Derrida (1991) opera na escrita da palavra différence, substituindo nela a segunda letra "e" pela letra "a", de modo a engajar nesse significante dois sentidos para o verbo diferir: 1. diferir no espaçamento, no entre-lugar do acontecimento da escrita em que uma suposta verdade que se pretendeu nela arquivar não se apresentará como presença incontestável e idêntica a si, mas como um rastro que abriga a disseminação da escrita nas inúmeras e diferentes leituras por vir. 2. Diferir no tempo, isto é, adiar o encontro prometido na escrita e na tradução com uma origem, uma verdade, um destino ou um sentido prometidos (DERRIDA, 1991). xada por Graciliano na sua escrita elíptica. Nessas intervenções, o processo tradutório induz a disseminação de sentidos contra o propósito que se espera de uma tradução, ou seja, contra a encarnação do "mesmo" em outro corpo linguístico. A tradução opera, portanto, o corte sobre outra blessure, alargando, assim, a ferida na escrita testemunhal de Graciliano.

\section{Tensão e escrita em Memórias do cárcere}

0 acontecimento traumático extrapola a língua, contudo, ao mesmo tempo, impõe o tormento nas palavras não ditas (ABRAHAM, TOROK, 1995; SELIGMANN-SILVA, 2005). Tormento à testemunha Graciliano Ramos, para quem seu relato estará sempre aquém das atrocidades presenciadas. Tensão que também acomete aqueles que se lançam a traduzir, para outra língua, suas chagas "cauterizadas", já "alteradas em conformidade com a técnica" (RAMOS, 2011, p. 196), ou seja, em conformidade com a língua na qual inscreve suas feridas, ferindo também essa língua, entalhando nela as agruras testemunhadas.

Ainda que perfure a língua, fincando nela suas dores, as palavras parecem não bastar para traduzir o choque da despersonalização experimentada, ao longo da estadia forçada na prisão e no porão inóspito do navio que o transportava junto a outros "subversivos". Não por acaso, outras recordações pungentes, como a de um corte cirúrgico e a dor de uma ferida mal cicatrizada, por vezes irrompem o relato:

Chegar-me-iam realmente aos ouvidos os sons estranhos? Seriam verdadeiros os rostos brancos, em desalento, vermelhos, nas convulsões da tosse, os vultos esmorecidos pelos cantos, cabeças erguendo-se à toa, desgovernadas, bocas escancarando-se no 
horror da sufocação? Talvez me achasse de novo no hospital, com o ventre rasgado, a queimar de febre (RAMOS, 1954, p. 137).

Foi preciso recorrer ao "ventre rasgado" na memória para traduzir a realidade inconcebível, para a qual faltavam referências na língua, ou seja, foi preciso recorrer a uma linguagem "própria" para ressignificá-la, atribuir-lhe sentido e torná-la disponível na memória.

Após sobreviver à viagem na "furna lôbrega" do navio Manaus, prestes a habitar outra prisão, a ferida da operação invade novamente a escrita. Na nova referência ao corte cirúrgico, a lembrança do seu ferimento é entrelaçada à fixação numa queimadura sobre um esqueleto tatuado no braço de outro prisioneiro: "as reminiscências da operação picavam-me a barriga. As névoas do meu espírito se diluíam num ponto, deixavam na claridade uma blusa de riscas indecisas, vestígios da queimadura grave, pedaços de esqueleto" (RAMOS, 1954, p. 222). Fagulhas da lesão experimentada no próprio corpo são entremeadas pela imagem da cicatriz e dos "restos da infame tatuagem" (RAMOS, 1954 , p. 221) sobre a pele do outro.

Nessas irrupções na textura da narrativa, evidencia-se o apelo a marcas no corpo, seja no próprio - como a cicatriz que incomoda e evoca os dias sofridos sobre o leito do hospital -, seja no corpo do outro que carrega a "medonha cicatriz" da queimadura, provocada pelo próprio portador do estigma, na tentativa de apagar a tatuagem "infame". Ambas marcas permanecem como feridas não curadas a causticar a pele, a memória e a escrita.

Embora ferido por outras lembranças, na tentativa de ressignificar a realidade inconcebível, o texto parece carregar ainda a angústia advinda da sensação de insuficiência do relato. É o que lemos na justificativa para os dez longos anos de silêncio: "além disso, julgando a matéria superior às minhas forças, esperei que outros mais aptos se ocupassem dela. Não vai aqui falsa modéstia, como adiante se verá" (RAMOS, 1954, p. 6).

Para interromper o silêncio do luto impedido e, então, dar início a esse processo de ressignificação do trauma, é necessário voltar à "furna". É preciso "descer para a cova" (RAMOS, 1954, p. 8) e abrir a cripta para que a narrativa flua. Talvez pelo peso que a tarefa de "escavar" o passado pressupõe, a testemunha considera a incumbência superior às suas forças, e, então, adverte que sua escrita pode não dar conta do compromisso martirizante, pois escavar o passado é como abrir a cicatriz.

Em tal circunstância, a narrativa se constrói testemunhando a tensão entre a demanda pelo relato e o receio de não lograr traduzi-lo "fielmente", ou seja, de não conseguir transmitir todo sofrimento diante da realidade absurda presenciada.

Análoga inquietação de "fidelidade" demandada e impossível é também o que os tradutores, Antoine Seel e Jorge Coli, experimentam na leitura das Memórias do cárcere, mas também o que atestam na própria escrita tradutória em Mémoires de prison. Não porventura, em breve texto sobre a escrita graciliânica, Seel e Coli descrevem o romancista alagoano como um "escritor que desconfia das palavras". Afirmam que, na narrativa, há uma dúvida constante quanto "a uma verdade que deve existir em algum lugar" (COLI; SEEL, 1986, p. 66). Falam, também, da incerteza do autor em relação à capacidade da língua em expressar tal verdade. Reafirmam, então, uma tensão tradutória no original, em que a escrita se torna um imperativo na busca por cercar um sentido e uma realidade que, todavia, "escapam".

Ao falar de uma verdade que Graciliano persegue em seu relato, mas que, ao mes- 
mo tempo, desconfia da possibilidade de exibi-la "em forma de palavras", Seel e Coli dão testemunho de um resto nas Memórias que excede sua leitura e, por conseguinte, a tradução. Apontam para a existência de um "segredo" encriptado, "em algum lugar", entre as reminiscências escritas e o trabalho na língua para cercar esse segredo, pois é essa conjuntura que move as traduções. Não há tradução que não busque encontrar alguma verdade enclausurada no original que não está, contudo, oferecida na superfície do corpo textual - faz-se necessário escavar, abrir esse corpo e, assim, ferir. Em toda escrita há uma instância secreta que não é da ordem de um segredo a ser revelado, mas que se prolonga na alteridade imponente dos textos, irredutível a qualquer decifração hermenêutica (DERRIDA, 2007). Os tradutores testemunham, portanto, não todos os sentidos e traumas exumados na escrita de Graciliano, mas a impossibilidade de esgotar tudo que se pretendeu dizer. Um segredo sempre resta não revelado nas leituras e nas traduções, impulsionando, ao mesmo tempo, os gestos de apropriação. Logo, o segredo que resiste à revelação é o que dá vida à escrita, vida que não é testemunhada fora das leituras e das traduções, pois por meio delas o texto fala e sobrevive.

O que Seel e Coli anunciam sobre a escrita de Graciliano Ramos é também a constatação de que o relato daquelas chagas não as exibe enquanto uma realidade presente na escrita, mas como um "excesso" de significação que transborda a partir da "ferida" inscrita na língua, no instante em que Graciliano também traduz, em seu texto, o corpo ferido pela experiência do cárcere.

Em que pese o doloroso esforço de rememoração e a linguagem que alude à dor no corpo seviciado, a aflição por cercar uma verdade persiste, como constata a leitura dos tradutores. Nesse sentido, o processo narrativo das Memórias do cárcere põe em movimento um constante embate para exumar o passado traumático que se esquiva, reabrindo a ferida para o testemunho do leitor. Em vista dessa conjuntura, vemos nesse relato a manifestação da concepção de escrita como o acontecimento de uma blessu$r e$, de "uma ferida que se abre, que não cicatriza”, de uma “ boca que fala lá onde está ferido" (DERRIDA, 2007, p. 325).

\section{Ferida, escrita e tradução entre Memórias e Mémoires}

A linguagem em torno do corpo seviciado, da iminência da morte e da chaga faz com que a ferida constitua o substrato do testemunho de Graciliano Ramos. Acrescido a esse aspecto cruciante, o ato escritural que promove a passagem da dor à língua marca, em si, o traço de uma ferida, o que nos aproxima ao pensamento da escrita como um rastro abandonado, ou seja, como signo de uma presença não mais presente (DERRIDA, 1991). A noção de escrita como rastro dialoga com a reflexão sobre blessure e o corpo-acorpo na língua.

A voz autoral não presente, cujo rastro é deixado no texto, constitui uma "lesão" marcada na forma da assinatura, pois evoca a ausência, até mesmo a ausência definitiva, do signatário (DERRIDA, 1991, 2007). Por outro lado, ela possibilita que o escritor continue a ser lido, ainda após a sua morte. A assinatura de um texto é, assim, o signo da "ausência do emissor, do destinador em relação à marca que abandona, que se separa dele e continua a produzir efeitos para além da sua presença e da atualidade presente do seu querer dizer, mesmo para além da sua própria vida" (DERRIDA, 1991, p. 354). 
Graciliano Ramos nos proporciona uma demonstração dessa ferida ao antecipar a iminência da sua morte e a possibilidade das suas Memórias virem à luz como obra póstuma: "estou a descer para a cova, este novelo de casos em muitos pontos vai emaranhar-se, escrevo com lentidão - e provavelmente isto será publicação póstuma, como convém a um livro de memórias" (RAMOS, 1954, p. 8).

A escrita tradutória enfatiza a doravante não presença daquele que assina, no instante em que oferece seu relato ao testemunho do leitor. Onde o narrador, no texto original, afirma estar descendo para a cova enquanto escreve suas memórias, os tradutores escrevem e contra-assinam: "J'ai déjà un pied dans la tombe" (RAMOS, 1988, p. 24) - expressão que permite a leitura do iminente fim da vida daquele que confessa já ter "um pé no túmulo". Ou seja, o autor estaria prestes a narrar suas experiências do leito de morte e, ao mesmo tempo, estaria descendo à cripta, a esse lugar da exumação.

A iminência da ausência absoluta da testemunha é reforçada no que a ouvimos anunciar, mais a frente, em francês: "et cette publication sera probablement posthume, comme il se doit pour un livre de Mémoires" (RAMOS, 1988, p. 24). A tradução ressalta, portanto, a ausência da testemunha - já advinda no instante da escrita - e o impasse do autor que anuncia seu curto tempo de vida em contraste com a magnitude e o ônus da incumbência de exumar aquelas memórias. Assistimos, então, a uma performance da assinatura de um texto como uma marca abandonada, um traço que indica a não-mais-presença de quem o grafou e, ao mesmo tempo, distingue a proveniência das chagas compartilhadas. Os tradutores acentuam o rastro da não-presença do signatário, quando, colocando à prova o corte que o segrega de sua marca, elencam outras possibilidades de significação em "J'ai déjà un pied dans la tombe".

No fragmento em português - "estou a descer para a cova" -, o enunciado parece compor, de forma mais alusiva, a trama que o antecede: - "ser-me-ia desagradável ofender alguém com esta exumação" (RAMOS, 1954, p. 8). 0 ato escritural é, aqui, aproximado à tarefa de desenterrar o passado e os mortos, assim como reforça o parágrafo anterior: "na verdade estávamos mortos, vamos ressuscitando" (RAMOS, 1954, p. 7). Logo, "descer para a cova”, parece-nos, sobretudo, implicar a ação de exumar as memórias, a vida e o fôlego para o testemunho, em detrimento do foco sobre a iminência da morte que os tradutores apreenderam e marcaram na sua escrita.

Mas a tradução não deixa de marcar o processo de exumação em curso, como observamos em: "nous étions bel et bien morts, et nous sommes en train de ressusciter" (RAMOS, 1988, p. 23). Esse momento do relato embasa a leitura de que as Memórias do cárcere dão início a um processo de exumação, uma vez que as testemunhas, até então "realmente mortas" - bel et bien morts -, estariam, naquele instante, ressuscitando - en train de ressusciter -, ao passo que a escrita iria se desdobrando.

As transformações no relato testemunhal de quem está beirando a morte e, nesse ínterim, ressuscitando na escrita, colocam à prova e em relevo a fissura no rastro de uma "voz autoral" que anuncia sua ausência. Além dessa blessure, outra se inscreve no ato escritural e se oferece no cruzamento entre Memórias e Mémoires. Falamos agora da cesura que aparta e, ao mesmo tempo, reúne, o passado à escrita. A inscrição desse presente da escrita, presente já ausente - dez anos após a prisão -, e de outro instante que se promete "resgatar" no relato, é a 
confissão de uma ferida, de um hiato, de um corte na escrita, mas é, também, a cicatriz no lugar do tecido que falta, entre passado e presente, e que não se reconstituirá jamais. Nessa perspectiva, o testemunho de Graciliano começa a se ferir nas primeiras linhas, ele tem início datando o instante da escrita, imprimindo nela a ferida e o luto por esse momento destinado à ausência.

Um sintoma dessa blessure desponta nas "vacilações dolorosas" da memória que constituem inquietação recorrente no livro, não somente no que concerne à tarefa de "exumar" o passado, mas também no que envolve as aflições vividas na prisão, entre elas, a confusão temporal e a sensação da perda de memória que a longa abstinência de alimento causara à testemunha. Confrontamo-nos com esse tormento quando, expressando o "enorme fastio" que lhe acometia, o narrador relata: "les souvenirs m'apparaissaient emmêlés, confus, ils s'évanouissaient à l'instant, en laissant en mon for intérieur de douloureux sillons noirs. Ces hiatus se succédaient, m'éloignaient de la réalité, me donnant certainement un air étrange et vague" (RAMOS, 1988, p. 70) ${ }^{6}$.

Não passa despercebida a menção a "douloureux sillons noirs" (dolorosos sulcos negros) e "hiatus" em referência à perda de memória que se experimentava. Ambas as expressões tramam uma significação em torno da ânsia de preservar intacta a memória do passado e da aflição diante do seu distanciamento.

É a partir desses "dolorosos" hiatos, no testemunho da separação entre presente da escrita e passado, que os tradutores operam

6 Trecho em Memórias do cárcere: "as lembranças me apareciam juntas, confusas, sumiam-se de repente, deixando-me no interior dolorosos sulcos negros. Esses hiatos sucediam-se, afastavam-me da realidade, com certeza me davam ar esquisito e vago" (RAMOS, 1954, p. 66). um segundo corte, entre escrita original e tradutória, alargando a blessure do ato escritural. Em meio à confusão temporal e à falta de apetite acompanhada pelas perdas de memória, os tradutores põem em evidência a "impossibilidade alarmante de fixar atenção na leitura” (RAMOS, 1954, 66) da qual o narrador se queixa. Se as manchas diante dos olhos dificultavam a leitura de Graciliano - "manchas dançavam-me diante dos olhos, dificultavam-me a leitura" (RAMOS, 1954, p. 66), para os tradutores, a leitura tornava-se penosa - des taches dansaient devant les yeux, rendaient pénible ma lecture (RAMOS, 1988, p. 70). Aqui, notamos não apenas a tentativa de traduzir a sensação que o autor descreve, mas também a impressão dos tradutores diante dessa escrita "aguda", "áspera", e, sobretudo, diante dos douloureux sillons noirs nos rastros que os acontecimentos deixavam, enquanto se "ausentavam" da memória, tornando o relato árduo como uma escavação.

0 vazio doloroso a dominar quem escreve, a confusão em relação ao tempo e o pessimismo quanto ao futuro pós-cadeia, esse conjunto de aflições se reúnem na leitura penosa do original que afeta também os tradutores. 0 processo de escrita não é menos exaustivo. Também não o é a tradução das feridas do sujeito encarcerado. Os tradutores demonstram testemunhar essa aflição que lemos no original e a elevam numa (re)escrita que transforma as Memórias, atestando e operando um segundo corte, uma outra blessure que, agora, se inscreve entre dois corpos textuais, duas línguas e duas escritas.

0 processo de exumação da memória convoca uma linguagem que trama a descida à cripta, a morte e a dor no corpo. A escrita tradutória remarca essa linguagem, até mesmo onde ela "falta" no original, e, assim, traz de volta o sofrimento que permeia 
o testemunho de Graciliano. Observamos esse movimento no fragmento em francês que relata a impressão do narrador diante do desespero e do pranto de um advogado também encarcerado: "cette image d'un désespoir total me plongea dans un sombre malaise" (RAMOS, 1988, p 92)77. O verbo plonger (mergulhar) marca uma diferença na escrita tradutória que, por outro lado, recupera o peso semântico que se faz eminente nas Memórias, o qual vimos elucidando: a descida à cripta, a queda, a exumação. Parágrafos a frente, atestamos a repetição desse signo e da carga semântica que sublinhamos na reflexão sobre o que poderia ter ocasionado o lamento presenciado: "peut-être y avait-il une raison plus grave: la soudaine disparition d'une certitude, avec plongeon dans les ténèbres, et impossibilité de trouver la moindre lumière (RAMOS, 1988, p. 94) ${ }^{8}$.

0 "mergulho nas trevas" ou "num sombrio mal-estar" se alinha ao "desmoronamento" que sucedia à testemunha (RAMOS, 1954, p. 41), à imersão naquele "mundo horrível de trevas e morte" (RAMOS, 1954, p. 7), ao mergulho "nos subterrâneos sociais" (RAMOS, 1954, p. 166), ao "mergulho definitivo" (RAMOS, 1954, p. 41), ou seja, à descida à cova, à experiência excruciante do "mal" e do "desastre" (RAMOS, 1954, p. 37), à lesão. Nesse sentido, a escolha tradutória pelo verbo "plonger" revela a profunda impressão que o contato com o corpo textual ferido do outro deixa nos tradutores e na sua escrita.

7 Trecho em Memórias do cárcere: "Essa imagem de completo desespero me causou sombrio mal -estar. Desapareceu - e algum tempo o desgraçado queixume ainda me feriu os ouvidos, e diante dos olhos me ficou a máscara luminosa, que semelhava tênue camada de parafina" (RAMOS, 1954, p. 94).

8 Trecho em Memórias do cárcere: "talvez houvesse ali coisa mais grave: a repentina supressão de uma certeza, mergulho na treva, impossibilidade de achar qualquer luz" (RAMOS, 1954, p. 97).
Impressão essa que fere e fica como uma marca, que demora em Mémoires de prison assim como demora, nos olhos do narrador que testemunha em francês, a máscara luminosa no rosto do advogado em prantos: "[...] le masque lumineux demeura sous mes yeux, ressemblant à une couche ténue de paraffine" (RAMOS, 1988, p. 92) ${ }^{9}$. No fragmento, "demeurer" - que traduz a ideia de "ficar" no trecho original - aponta para sentidos envolta do que não se apaga e, portanto, permanece, se prolonga, habita o corpo supliciado que está descendo à cova, à sua última morada. É também porque "demeurer", como substantivo, compõe a expressão "dernière demeure" (última morada, onde habitam os mortos) que esse significante remete-nos ao campo semântico da ferida e da morte por onde as Memórias transitam.

A inscrição de palavras cuja significação se desdobra em torno do "sombrio mal-estar" do cárcere, para remarcar a blessure onde ela se faz tênue no original, suplementa esse corpo textual revelando suas feridas e, ao mesmo tempo, atestando uma suposta "falta". Outro momento da escrita tradutória oferece-nos exemplo mais emblemático desse gesto de suplementação. Trata-se da cena em que o narrador descreve sua entrada na "furna lôbrega" do porão do navio Manaus - onde seria transportado para o Rio de Janeiro. Durante minutos sem compreender onde se achava, a testemunha descreve as primeiras impressões: "un espace vague, aux limites incertaines, couvert d'une ombre laiteuse. La nuit était tombée à l'extérieur, mais nous n'aurions pas pu nous prononcer, en cet endroit, entre le jour et la nuit. (RAMOS, 1988, p. 115) ${ }^{10}$. A expressão

9 Trecho em Memórias do cárcere: "[...] diante dos olhos me ficou a máscara luminosa, que semelhava tênue camada de parafina" (RAMOS, 1954, p. 94).

10 Trecho em Memórias do cárcere: "Espaço vago, 
"en cet endroit" (naquele lugar) aponta, de modo menos elíptico, ao local "velado" em "ali" - "ali duvidaríamos se era dia ou noite" (RAMOS, 1954, p. 125). Vemo-nos diante da tentativa de preencher um "vazio" de palavras, um silêncio que, em contrapartida, pode germinar um excesso de sentidos, entre eles: ali naquele porão inóspito, naquela privação de liberdade, naquela experiência de um "enorme dano".

Essa mudança no corpo do texto original atenua o aspecto lacônico da escrita de Graciliano Ramos, que preza pela "redução da linguagem àquele mínimo de recursos que a faz funcionar sem perder a carga explosiva que encerra" (MIRANDA, 2004, p. 13). A economia e o rigor da escrita do romancista não são ignorados pelos tradutores: "seu processo é antes o do corte, da supressão, da redução" (SEEL; COLI, 1986, p. 66). Embora reconheçam esse traço na obra de Graciliano, não logram repeti-lo na tradução. Esbarram, primeiro, na diferença irreconciliável entre as línguas e, segundo, nos cortes abertos na escrita: entre passado e presente, entre o testemunho "privilegiado" do sujeito encarcerado e a tradução. 0 esforço de "resgatar" a cena testemunhada, na qual os tradutores não estavam presentes e que veem silenciada "ali", constitui tentativa de fechar o corte que segrega a tradução do testemunho "privilegiado". À revelia desse esforço, o gesto tradutório enseja a diferença e alarga tal fissura.

Em que pese a impossibilidade de fechar a cesura entre presentes e escritas e, então, reconstruir o sofrimento do outro, a leitura da tradução propicia-nos a escuta do dano profundo da condenação, assim como a passagem a seguir ressoa:

A peine avais-je fermé les yeux dans une légère somnolence, quelqu'un m'avait secoué

de limites imprecisos, envolto em sombra leitosa. Lá fora anoitecera; ali duvidaríamos se era dia ou noite" (RAMOS, 1954, p. 125). et soufflé à l'oreille: "Voyager." Vers où? Cette idée de pouvoir être menés à droite ou à gouche, sans explications, est extrêmement douloureuse, nous n'arrivons pas à nous familiariser avec elle. [...] Nous avons l'impression qu'on désire seulement nous écraser, nous pulvériser, nous supprimer le droit de nous asseoir ou de dormir si nous sommes fatigués. Cette dépersonnalisation est-elle nécessaire? Après avoir été soumis à pareil régime, un individu est acquitté et relâché. Cet acquittement ne lui est guère utile: habitué à se déplacer comme si on le tirait par des fils, il se libérera difficilement. On l'a condamné avant son jugement, et rien ne compense cet horrible dommage (RAMOS, 1988, p. 54,55) ${ }^{11}$.

Lemos o relato da aflição advinda da violenta despersonalização que a testemunha experimentou ao lhe serem negadas informações sobre o destino para onde estava prestes a embarcar. Negavam-se aos presos qualquer traço de reconhecimento da sua condição humana, e a interdição da comunicação constituía um meio para essa negação. Na tentativa de desumanização dos detentos, marcas indeléveis são deixadas no prisioneiro a ponto de a absolvição não ser o suficiente para assegurar-lhe a liberdade. Logrado transpor aquelas grades, ainda carregaria o peso dos tamancos usados na cadeia. Atado, para sempre, à condição de

11 Trecho em Memórias do cárcere: "Mal fechara os olhos numa leve sonolência, alguém me sacudira e soprara ao ouvido: “-Viajar.” Para onde? Essa ideia de nos poderem levar para um lado ou para outro, sem explicações, é extremamente dolorosa, não conseguimos familiarizar-nos com ela. [...]Temos a impressão de que apenas desejam esmagar-nos, pulverizar-nos, suprimir o direito de nos sentarmos ou dormir se estamos cansados. Será necessária essa despersonalização? Depois de submeter-se a semelhante regime, um indivíduo é absolvido e mandam-no embora. Pouco lhe serve a absolvição: habituado a mover-se como se o puxassem por cordéis, dificilmente se libertará. Condenaram-no antes do julgamento, e nada compensa o horrível dano" (RAMOS, 1954, p. 45, 46). 
testemunha do cárcere, o narrador assevera: rien ne compense cet horrible dommage - nada compensa o horrível dano.

A recriação da passagem pelos tradutores reinscreve a violência da subordinação imposta na voz passiva ressonante nos seguintes trechos: "cette idée de pouvoir être menés à droite ou à gauche”, "après avoir été soumis", "un individu est acquitté et relâché". Ao omitir quem pratica a ação - mesmo já se tratando de um sujeito indefinido no texto original: "essa ideia de nos poderem levar" -, pondo em maior evidência a violência sofrida e o sujeito que a sofre, os tradutores ressaltam a lesão da despersonalização dos encarcerados. Estes deixam de responder ativamente, sendo então levados - menés -, submetidos - soumis -, esmagados - écrasés -, pulverizados - pulvérisés -, absolvidos - acquittés - e, por fim, liberados - relâchés - inutilmente.

0 choque da despersonalização, o trauma da cadeia, a blessure que se inscreve em Memórias do cárcere atravessam a escrita em Mémoires de prison, passando, todavia, pelo crivo do olhar dos tradutores, pelo "filtro" de uma outra língua e outra escrita. Na passagem do português para o francês, entrevemos também certa tensão tradutória nos "hiatos" suplementados, isto é, nas referências acrescidas ao cenário onde se passa a trama narrada, cenário onde os tradutores nunca estiveram presentes e, portanto, precisariam "resgatar", costurar essa "cesura" aberta, "preencher" o vazio. Contudo, ao preencher a "falta", os tradutores dão testemunho dessa fissura e da impossibilidade de saná-la sem que outra ferida irrompa: a inevitável "rasura" no corpo textual das Memórias do cárcere.

\section{Últimas considerações}

Escrita e tradução se anunciam como uma ferida aberta, o hiato, o vazio que as pala- vras não logram preencher, mas, ao contrário, atestam sua dimensão secreta. Assim como as Memórias não trazem as chagas do cárcere a uma presença "consoladora" na linguagem - não obstante as metáforas e as referências a outras feridas que compõem a narrativa -, tampouco a escrita tradutória logra amarrar o corpo ferido do outro ao corpo textual em outro idioma. A tradução, que faz sobreviver o testemunho do romancista em Mémoires de prison, não repete o original "como tal", mas faz irromper outras significações e outras feridas ensejadas pelo contato com o relato contundente de Graciliano Ramos.

Sua escrita é, desse modo, como uma cicatriz no corpo do prisioneiro, um estigma que testemunha a impressão e, ao mesmo tempo, a não-mais-presença dos acontecimentos que deixaram sua marca no corpo e perturba quem se põe diante dessa cicatriz escritural não fechada ou curada plenamente. Aos tradutores, diante dessa escrita do sujeito supliciado, resta testemunhá-la como o acontecimento, em si, de uma blessure, como um corte perturbador entre os traumas inomináveis e a escrita, corte que não se desfaz, como "o hiato de uma ferida cujos lábios não se fecham, não se juntam jamais" (DERRIDA, 2003, p. 54, tradução nossa) ${ }^{12}$.

Aludindo ao que Graciliano afirmou sobre sua tarefa de escritor, o texto original dissemina as chagas daquele que decidiu abri-las e partilhá-las com quem é tocado pelos "mesmos" males (RAMOS, 2011). Na impossibilidade de encontrar a total identificação com o que lhe atormenta, Graciliano terá destinado suas chagas àqueles que se abrirem ao risco de serem feridos por sua escrita. A blessure que constitui seu relato é

12 "[...] le hiatus d'une blessure dont les lèvres ne se fermente ou ne se rassemblent jamais". 
quase um schibboleth13, dado e prometido "ao outro singular para que este possa compartilhá-lo e para que ele entre, ou que ele saia, para que ele passe a porta, a linha, a fronteira, o limiar" (DERRIDA, 1986, p. 108, tradução nossa) ${ }^{14}$.

Seel e Coli demonstram responder a esse desafio, entrando no texto pela sua fratura, atestando as impressões profundas do seu encontro com a escrita penosa de Graciliano Ramos, e fazendo-a proliferar e sobreviver. Os tradutores, ao engendrarem a transformação de uma língua à outra, elevam o original, reforçando a fissura, o trauma, a chaga que se faz entrever na escrita do cárcere. No entanto, essa elevação não acontece sem rasura, sem fissura, sem trauma, pois, retomando Derrida (2007), não há tradução que exclua o risco dessa violência.

\section{Referências}

ABRAHAM, Nicolas; TOROK, Maria. A casca e o núcleo. Tradução por Maria José R. Faria Coracini. São Paulo: Escuta, 1995.

\section{DERRIDA, Jacques. Schibboleth pour Paul Ce-}

13 Schibboleth anuncia um traço de pertencimento e segregação. Derrida (1986) traduz essa palavra como uma marca no corpo da língua que segrega e, ao mesmo tempo, reúne um certo número de sujeitos que compartilham um tal "segredo", uma diferença que não é simplesmente da ordem de um significado a ser transmitido e traduzido. Desse modo, o autor a aproxima à força de significação da circuncisão, desse estigma no corpo que segrega e reúne aqueles que carregam essa cicatriz, que compartilham os traumas, os significados e as leituras em torno do corpo judeu ferido. Schibboleth seria, portanto, a circuncisão no corpo da língua, uma ferida que permite a travessia, a passagem, a entrada no texto daqueles que partilham a "mesma" chaga, como quem partilha um segredo, ou daqueles que se entregam ao risco de ser ferido (DERRIDA, 1986).

14 "Le schibboleth est donné ou promis par moi (mein Wort) à l'autre singulier, celui-ci, pour qu'il le partage et qu'il entre, ou qu'il sorte, pour qu'il passe la porte, la ligne, la frontière, le seuil". lan. Paris: Galilée, 1986.

DERRIDA, Jacques. Margens da filosofia. Tradução por Joaquim Torres Costa e António M. Magalhães. Campinas: Papirus, 1991.

DERRIDA, Jacques. Passages - du traumatisme à la promesse. In: DERRIDA, Jacques. Points de suspension: Entretiens. Paris: Galilée, 1992. p. 385-409.

DERRIDA, Jacques. Béliers - Le dialogue ininterrompu: entre deux infinis, le poème. Paris: Galilée, 2003.

DERRIDA, Jacques. A verdade ofensiva ou o corpo-a-corpo das línguas. Entrevista a Évelyne Grossman. Tradução por Élida Ferreira. Especiaria: Cadernos de Ciências Humanas, Ilhéus, v. 10, n. 17, p. 305-329, 2007.

KIFFER, Ana. Corpo, memória, cadeia: o que pode o corpo escrito? Alea, Rio de Janeiro, v.8, n.2, p. 263-280, jul./dez. 2006.

MIRANDA, Wander Melo. Graciliano Ramos. São Paulo: Publifolha, 2004.

RAMOS, Graciliano. Memorias do cárcere. 1ํㅡㄴ Volume: Viagens. 3.ed. Rio de Janeiro: Jose Olympio. 1954.

RAMOS, Graciliano. Mémoires de prison. Tradução por Antoine Seel, Jorge Coli. Paris: Gallimard, 1988.

RAMOS, Graciliano. Cartas. 8 ed. Rio de Janeiro: Record, 2011.

SEEL, Antoine; COLI, Jorge. Um escritor que desconfia das palavras. Folha de São Paulo, São Paulo, Ilustrada, p. 66, 16 ago. 1986.

SEEL, Antoine. COLI, Jorge. Préfacé. In: RAMOS, Graciliano. Mémoires de prison. Tradução por Antoine Seel, Jorge Coli. Paris: Gallimard, 1988, p. 9- 16.

SELIGMANN-SILVA, Márcio. Trauma, testemunho e literatura. In: SELIGMANN-SILVA, Márcio. 0 local da diferença: ensaios sobre memória, arte, literatura e tradução. São Paulo: Editora 34, 2005.

Recebido em: $15 / 10 / 2020$

Aprovado em: 31/10/2020 